\title{
Treatment Technologies for Cooling Water Blowdown: A Critical Review
}

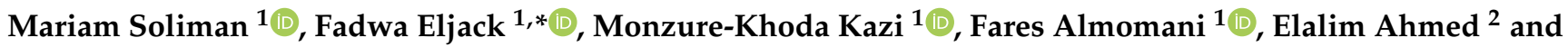 \\ Ziad El Jack ${ }^{2}$ (1)
}

check for

updates

Citation: Soliman, M.; Eljack, F.; Kazi, M.-K.; Almomani, F.; Ahmed, E.; El Jack, Z. Treatment Technologies for Cooling Water Blowdown: A Critical Review. Sustainability 2022, 14, 376.

https://doi.org/10.3390/su14010376

Academic Editors: José Luis Campos, Anuska Mosquera Corral,

Ángeles Val del Río and Alba

Pedrouso Fuentes

Received: 30 November 2021

Accepted: 27 December 2021

Published: 30 December 2021

Publisher's Note: MDPI stays neutral with regard to jurisdictional claims in published maps and institutional affiliations.

Copyright: (C) 2021 by the authors. Licensee MDPI, Basel, Switzerland. This article is an open access article distributed under the terms and conditions of the Creative Commons Attribution (CC BY) license (https:// creativecommons.org/licenses/by/ $4.0 /)$.
1 Department of Chemical Engineering, College of Engineering, Qatar University, Doha P.O. Box 2713, Qatar; mariam.soliman@qu.edu.qa (M.S.); kazi0001@qu.edu.qa (M.-K.K.); falmomani@qu.edu.qa (F.A.)

2 Ministry of Municipality and Environment (MME), Infrastructure Planning Department (IPD), Doha P.O. Box 2727, Qatar; EAAHMED@mme.gov.qa (E.A.); zeljack@hotmail.com (Z.E.J.)

* Correspondence: Fadwa.Eljack@qu.edu.qa

\begin{abstract}
Cooling water blowdown (CWBD) generated from different industries and district cooling facilities contains high concentrations of various chemicals (e.g., scale and corrosion inhibitors) and pollutants. These contaminants in CWBD streams deem them unsuitable for discharge into surface water and some wastewater treatment plants. The pollutants present in CWBD, their sources, and the corresponding impacts on the ecosystem are discussed. The international and regional (Gulf states) policies and regulations related to contaminated water discharge standards into water bodies are examined. This paper presents a comprehensive review of the existing and emerging water treatment technologies for the treatment of CWBD. The study presents a comparison between the membrane (membrane distillation (MD), reverse osmosis (RO), nanofiltration (NF), and vibratory shear enhanced membrane process (VSEP)) and nonmembrane-based (electrocoagulation (EC), ballasted sand flocculation (BSF), and electrodialysis (ED)) technologies on the basis of performance, cost, and limitations, along with other factors. Results from the literature revealed that EC and VSEP technologies generate high treatment performance (EC $99.54 \%$ reduction in terms of silica ions) compared to other processes (membrane UF with reduction of $65 \%$ of colloidal silica). However, the high energy demand of these processes (EC 0.18-3.05 kWh $/ \mathrm{m}^{3}$ and VSEP $2.1 \mathrm{kWh} / \mathrm{m}^{3}$ ) limit their large-scale applications unless connected with renewable sources of energy.
\end{abstract}

Keywords: cooling water blowdown; treatment technologies; contaminants; membrane technologies; emerging technology

\section{Introduction}

Scarcity of freshwater is one of the eminent dangers that can be found in many countries around the world. It can be considered a global problem as a result of the rapid growth of population; industrialization; and, more importantly, the pollution caused to fresh water from many sources. The water supply could be increased beyond the natural hydrological cycle by implementing energy-efficient and sustainable technologies for recycling and reusing the wastewater instead of releasing it into water bodies, which may cause further problems and diseases. When all systems that consume water optimize their usage and apply developed technologies, it will ensure that water will be conserved and secured, with considerable savings in freshwater consumption being realized. Although water is consumed by many sectors and processes in different industries, cooling tower systems require and consume a significant amount of water in industries, power plants, universities, and government buildings [1]. Cooling towers are units that provide an energy-efficient and cost-effective operation for devices in need of cooling [2,3]. During the process of cooling, water is continuously recirculated, while some water evaporates; this leads to an increase in the concentration of salt and contaminants to high levels. As the number of recirculation cycles increases, the solubility of various solids is reduced; consequently, solids 
will form a shale shape on the warm surface of the condenser pipes. The formed scales in the cooling tower unit cause a reduction in the heat transfer efficiency as they insulate the metal surface of the tower [4]. With further recirculation of the concentrated water, permanent damage can occur to the cooling system [1]. Therefore, this highly concentrated water stream is discharged out of the system as a cooling water blowdown water (CWBD). The discharge may contain iron oxides, calcium phosphate, calcium carbonate, magnesium silicate, silica, and many other contaminants and pollutants [4]. CWBD discharge helps enhance heat transfer efficiency since the concentration of the silica and hardness ions in the circulated water is kept under the level where scales can be formed [5]. A make-up stream of fresh water is used to compensate for the amount of water lost in evaporation and CWBD discharge.

Water shortages and the rising prices of freshwater have encouraged many industries to reduce their dependence on freshwater and focus on using treated water as an alternative [4]. For example, in GCC countries, lack of freshwater resources forces these countries to use the treated sewage effluent (TSE) as CWBD. On the other hand, various treatment technologies have been used or proposed to treat any type of wastewater and sustain the available water resources. Different technologies have been used to treat the CWBD. Reverse osmosis (RO), electrodialysis (ED), nanofiltration (NF), electrocoagulation (EC), vibratory shear enhanced membrane process (VSEP), ballasted sand flocculation (BSF), and membrane distillation (MD) were usually proposed as suitable technologies. Saha et al. [6] evaluated the effect of operational parameters and the type of electrodes on the removal of organic pollutants from CWBD when electrochemical oxidation is applied as a pre-treatment technology. In a different paper, Saha et al. [7] studied the treatment of CWBD by combining constructed wetlands with the electrochemical oxidation process. The study showed that the integrated system of VFCW-EO had a better ability to remove organic chemicals, such as TOC, COD, and the corrosion inhibitor benzotriazole, than the EO and VFCW systems.

Wagner et al. [8] reviewed the possibility of using electrochemical oxidation for the removal and conditioning of chemicals out of CWBD, and results showed an excellent treatment performance represented by removal rates of $85 \%$ and $51 \%$ for COD and TOC respectively, with the $\mathrm{BDD}$-anode. Additionally, Li et al. [9] recently conducted a toxicity assessment, technical performance, and economic evaluation for the treatment of CWBD water by implementing adsorption-electrocatalytic oxidation. Results showed that $\mathrm{PANI} / \mathrm{TiO}_{2}$, which is polyaniline-modified $\mathrm{TiO}_{2}$, was a promising adsorbent for phosphorus and organics removal from CWBD.

The aforementioned literature reviews showed that the conducted studies, reviews, and published work on the treatment of CWBD water are limited. There is a clear gap in knowledge related to the performance of different treatment technologies in tackling the CWBD problem. The impact of water quality parameters and the discharge volume on the process's performance and the energy demand required further investigation. Reviewing various treatment technologies will provide an idea about the possible alternatives to treat the effluent streams from cooling towers, which will make decision-makers aware of the potential processes for treating purposes. Additionally, evaluating critical criteria, such as the technologies' cost, efficiency, and effluent quality, is highly important in selecting the most sustainable, green, and economical option. Regulations and standards are another important evaluation factor as they determine the maximum level of contaminates concentration permitted at the endpoint or the discharging area. Therefore, this work presents a comprehensive review and comparison between the existing and emerging water treatment technologies for the treatment of CWBD. Different treatment technologies of CWBD were reviewed and evaluated on the basis of process scale, maintenance, chemical additive requirements, energy consumption, quality of permeate and sludge, and more importantly removal ability of contaminants and cost analysis. The impacts of contaminants presented in CWBD on the environment and human health, as well as the operations of cooling tower systems, are presented and discussed. In addition, the regional and international policies 
and regulations related to contaminated water discharge standards into water bodies are explored and discussed. The paper highlights regulations and standards of wastewater discharged to sewage treatment plants, the marine environment, and irrigation purposes.

\section{Overview of CWBD Pollutants and Impacts}

As a part of the cooling processes in cooling towers, a portion of the concentrated water is discharged out of the system as CWBD to control the concentration level of different ions and compounds in the cooling tower. In this section, pollutants found in CWBD are reviewed, with a focus on the ones of concern and their impacts.

\subsection{CWBD Contaminants}

Studying the available pollutants in CWBD will help in reusing it or selecting an end of pipe solution to reduce these pollutants before discharging the effluent into water bodies. The type and the quantity of contaminants available in that effluent vary from one system to another and depend on many factors. For instance, the source of the inlet and make-up water to the cooling tower has a great impact on the presence of various contaminants over others. The types of chemicals used for treatment purposes, as inhibitors or even as an anti-corrosion inside the towers, can significantly affect the composition of chemicals found in water. Stratton et al. [10] investigated the water quality parameters of the blowdown and make-up water from 11 cooling towers. The results showed that the chemical composition of the water varied greatly between the cooling towers for many reasons, such as the make-up water chemistry and the chemicals used for treatment.

Table 1 presents the most common contaminants in CWBD stream from different recent references. Ahmed et al. [11] showed an excellent representation of the CWBD characteristics regarding the available contaminates and their corresponding concentrations for different streams and references. Common contaminants are found in all or at least most effluents, including calcium ions, magnesium ions, and chloride (see Table 1). Sulphate, phosphate, iron and sodium ions, and TDS, among others, can be also found in the CWBD. It is noticeable that the presence of some contaminants differs between the effluent streams. One primary reason could be that the studies did not conduct complete characterization analysis for all available contaminants in CWBD, and that can be due to the scope of the focus of their studies. For example, the target of Abdel-shafy and his colleagues in their paper [4] was to treat CWBD from calcium, magnesium, and silica ions using magnesium electrodes in electrocoagulation (EC) technology; hence, their analysis focus was only on these ions. Hong and other authors in a thesis project [1] focused on reducing the total dissolved solids (TDS) level in CWBD to be equivalent to tap water. Differences in levels of contaminants are because of the amount and type of chemicals used in the cooling tower as well as the cyclic concentration. Moreover, increasing the evaporation rate in cooling towers will increase the concentration of ions [12,13]. The differences in rates of evaporation depending on the design and the efficiency of the tower. The quality of air passed in the cooling tower also impacts the characterization of CWBD water because air with a high amount of dust will increase the total amount of suspended solids and turbidity of the CWBD stream compared to filtered air [11].

\subsection{Contaminants of Concerns in CWBD and Their Impacts}

The effluent from the cooling tower contains a wide range and various types of contaminants that can significantly affect the environment and human life. Total dissolved solids (TDS) at high concentrations are considered as one of the major contaminants. Dickerson and Vinyard [14] reported that the elevated concentrations of TDS caused the extinctions of two nonindigenous species of fish in Walker Lake, Nevada. In a standard desalination plant, 50,000 to 70,000 ppm are considered as a common range for the effluent TDS in CWBD [1,15]. In addition, elevated levels of TDS in water streams can cause scaling and corrosion to the pipelines [1], consequently affecting transport efficiency and increasing maintenance costs. 
Weber-Scannell et al. [16] discussed the effects of TDS on aquatic organisms. Discharging CWBD water with a high amount of phosphate $\left(\mathrm{PO}^{3-}\right)$ into water bodies increases the growth of algae, leading to oxygen depletion in the water [17], and eventually mortality of aquatic creatures such as fish, flora, and fauna [18].

Groundwater is a freshwater resource that can be highly impacted by contaminants found in CWBD. Ions of sodium $\left(\mathrm{Na}^{+}\right)$, magnesium $\left(\mathrm{Mg}^{2+}\right)$, sulfate $\left(\mathrm{SO}_{4}{ }^{2-}\right)$, potassium $\left(\mathrm{K}^{+}\right)$, chloride $\left(\mathrm{Cl}^{-}\right)$, calcium $\left(\mathrm{Ca}^{2+}\right)$, and bicarbonate $\left(\mathrm{HCO}_{3}{ }^{-}\right)$are the main inorganic ions present in natural waters. However, increasing their concentrations can cause health as well as environmental issues. For example, physical inconveniences such as diarrhea and skin irritation can be caused when the groundwater is highly concentrated with sulphate [19]. Increasing the level of magnesium and calcium as a result of injecting wastewater streams such as CWBD can cause water hardness. For some developing countries, groundwater is their main or only source of drinking water, and such contaminants threaten their water security. Such hardness ions do not only affect groundwater, but they can cause scaling and other mechanical problems to the cooling towers when recycled without treatment [20]. Other contaminants such as arsenic in groundwater with elevated levels can cause cancer [21], loss of limbs, or even lead to death in critical cases [19,22]. The drinking of fluoride-concentrated groundwater can have an adverse impact on the growth of children and at extreme concentrations, it can lead to death because of its toxicity [19]. Trace of heavy metals such as zinc, chromium, lead, nickel, silver, aluminum, copper, cadmium, and cobalt also exist naturally in groundwater, and their concentrations can be increased with human activities [23,24], consequently affecting the ecosystem as well as making groundwater unfit for human consumption. Zinc is considered a poisoning metal that causes skin irritations, anemia, and other infections [18,25]. The presence of lead in animal and human bodies impacts the synthesis process of hemoglobin that can lead to anemia and more severe problems [18]. Cadmium is toxic for organisms that live in the aquatic environment and can cause problems to the kidney and liver. In contrast, chromium can cause cancer for humans as well as skin irritation [18].

Table 1. Common contaminants available in CWBD water.

\begin{tabular}{|c|c|c|c|c|c|}
\hline Parameter & Unit & [4] & [11,26] (J. Löwenberg, 2015) & [7] & {$[1] * * * *$} \\
\hline $\mathrm{pH}$ & & 8.2 & 7.9 & $6.8 \pm 0.2$ & \\
\hline Calcium $\left(\mathrm{Ca}^{2+}\right)$ & $\mathrm{mg} / \mathrm{L}$ & $392 * *$ & 1204 ** & $338 \pm 7.6$ & 125.9 \\
\hline Magnesium $\left(\mathrm{Mg}^{2+}\right)$ & $\mathrm{mg} / \mathrm{L}$ & $280 * *$ & $259 * *$ & $58 \pm 2.4$ & 12.5 \\
\hline Silica $\left(\mathrm{SiO}_{2}\right)$ & $\mathrm{mg} / \mathrm{L}$ & $27^{* * *}$ & 0.9 & & \\
\hline Chloride $\left(\mathrm{Cl}^{-}\right)$ & $\mathrm{mg} / \mathrm{L}$ & 162 & 500 & $458 \pm 10$ & 205.32 \\
\hline $\operatorname{Zinc}\left(\mathrm{Zn}^{2+}\right)$ & $\mathrm{mg} / \mathrm{L}$ & 1.2 & & & \\
\hline Phosphate $\left(\mathrm{PO}_{4}{ }^{3-}\right)$ & $\mathrm{mg} / \mathrm{L}$ & $6.61 *$ & 5.9 & & \\
\hline Iron $\left(\mathrm{Fe}^{2+}\right)$ & $\mathrm{mg} / \mathrm{L}$ & 0.1 & & & 0.6343 \\
\hline Sulphate $\left(\mathrm{SO}_{4}{ }^{2-}\right)$ & $\mathrm{mg} / \mathrm{L}$ & 711 & & $1043 \pm 52$ & 469.05 \\
\hline Aluminium $\left(\mathrm{Al}^{3+}\right)$ & $\mathrm{mg} / \mathrm{L}$ & & & & 0.0596 \\
\hline Barium $\left(\mathrm{Ba}^{2+}\right)$ & $\mathrm{mg} / \mathrm{L}$ & & 0.145 & & 0.1142 \\
\hline Potassium $\left(\mathrm{K}^{+}\right)$ & $\mathrm{mg} / \mathrm{L}$ & & & $75 \pm 1.3$ & 8.1 \\
\hline Sodium $\left(\mathrm{Na}^{+}\right)$ & $\mathrm{mg} / \mathrm{L}$ & & & $334 \pm 2.9$ & 262.8 \\
\hline Copper $(\mathrm{Cu})$ & $\mathrm{mg} / \mathrm{L}$ & & & & 0.224 \\
\hline Strontium $\left(\mathrm{Sr}^{2+}\right)$ & $\mathrm{mg} / \mathrm{L}$ & & 1.500 & & 1.0853 \\
\hline Bromide $\left(\mathrm{Br}^{-}\right)$ & $\mathrm{mg} / \mathrm{L}$ & & & & 43.35 \\
\hline Fluorine $(\mathrm{F})$ & $\mathrm{mg} / \mathrm{L}$ & & & & 8.1 \\
\hline Total suspended solids (TSS) & $\mathrm{mg} / \mathrm{L}$ & & 12 & & \\
\hline Total dissolved solids (TDS) & $\mathrm{mg} / \mathrm{L}$ & 1297 & & & 1329 \\
\hline Total organic carbon (TOC) & $\mathrm{mg} / \mathrm{L}$ & & & $41 \pm 1.3$ & \\
\hline $\begin{array}{l}\text { Chemical oxygen demand } \\
\text { (COD) }\end{array}$ & $\mathrm{mg} / \mathrm{L}$ & & & $107 \pm 6.4$ & \\
\hline Nitrate $\left(\mathrm{NO}^{3-}\right)$ & $\mathrm{mg} / \mathrm{L}$ & & 86.7 & $57 \pm 1.8$ & \\
\hline Turbidity & NTU & 7.93 & 7.3 & & \\
\hline CWBD water source & & $\begin{array}{l}\text { Effluent of a urea } \\
\text { fertilizer plant }\end{array}$ & $\begin{array}{l}\text { From a cooling tower }(\mathrm{CT}) \\
\text { next to the Dow premises in } \\
\text { Terneuzen (The Netherlands) }\end{array}$ & $\begin{array}{c}\text { From }(\mathrm{CT}) \text { of Dow } \\
\text { Benelux BV (Terneuzen, } \\
\text { The Netherlands) }\end{array}$ & $\begin{array}{l}\text { From CSULB } \\
\text { cooling towers }\end{array}$ \\
\hline
\end{tabular}

* Total phosphate as $\mathrm{PO}_{4} .{ }^{* *} \mathrm{As} \mathrm{CaCO}_{3} .{ }^{* *}$ Silicates as $\mathrm{SiO}_{2} .{ }^{* * *}$ Unit changed from $\mu \mathrm{g} / \mathrm{L}$ to $\mathrm{mg} / \mathrm{L}$. 
Different types of anti-corrosion chemicals such as chromates, nitrites, molybdates, and tungstates [27], as well as biocides such as glutaraldehyde and isothiazolin [28] are added to cooling towers to inhibit the growth of algae, fungi, and bacteria available in the cooling water. Such chemicals and compounds are highly toxic for all living things and the environment when dumped into water bodies [1].

Using wastewater and CWBD as an example for irrigation applications is commonly applied in many countries to reduce the water scarcity problem [29]. However, the effect of available contaminates in such streams should be considered since they can contaminate soil and crops with lasting impacts on the whole biological chain [30]. Ingestion of such food can result in accumulated levels of contaminants that lead to many of the above-mentioned diseases [29,31].

Aside from the direct usage of wastewater, some facilities discharge it to sewers to be treated in sewage treatment plants. The design of the treatment system differs on the basis of the type of sewage. The availability of grit chambers, screens, sedimentation tanks, and other units will greatly affect the treatment ability of the sewage treatment plants in terms of many aspects [32]. The efficiency, maintenance costs, and the penetration of contaminants with the effluent water could be some of the impacts of industrial wastewater on the sewage treatment plants that can adversely affect the environment. The sewage treatment systems are designed on the basis of technologies that can handle certain types and concentrations of contaminants, and variations can lead to the production of water with low quality or cause a damage to the system. According to the study performed by Pophali et al., influent with high TDS can interfere with the oxygen transfer essential for biological metabolism, hence affecting the efficiency of the activated sludge process.

Considering the environmental, health, and operational, undesirable impacts of CWBD contaminants on different water systems, there is a need to consider water treatment technologies as means of managing CWBD. The following sections of the paper present reviews of existing technologies and evaluate them on the basis of their technical, environmental, and economic performance.

\section{Overview on CWBD Water Treatment Technologies}

The technologies that will be reviewed in this section are extensively implemented for the treatment of wastewater and CWBD as a type of wastewater. There are many pre-treatment processes used for CWBD water that can screen solids and remove other contaminants to reduce the load on the major treatment technologies, which are used to remove dissolved contaminants, suspended solids, etc. However, the focus here will be on the treatment processes, which were found to be applicable and suitable for CWBD treatment according to conducted studies and the literature; the technologies are presented in Figure 1. Non-membrane-based technologies include EC and BSF, while membrane-based technologies are MD, ED, RO, NF, and an emerging technology called VSEP membrane process. All these technologies are reviewed in this section, then evaluated on the basis of their ability for removal of contaminants, cost, and other factors in Section 5. 


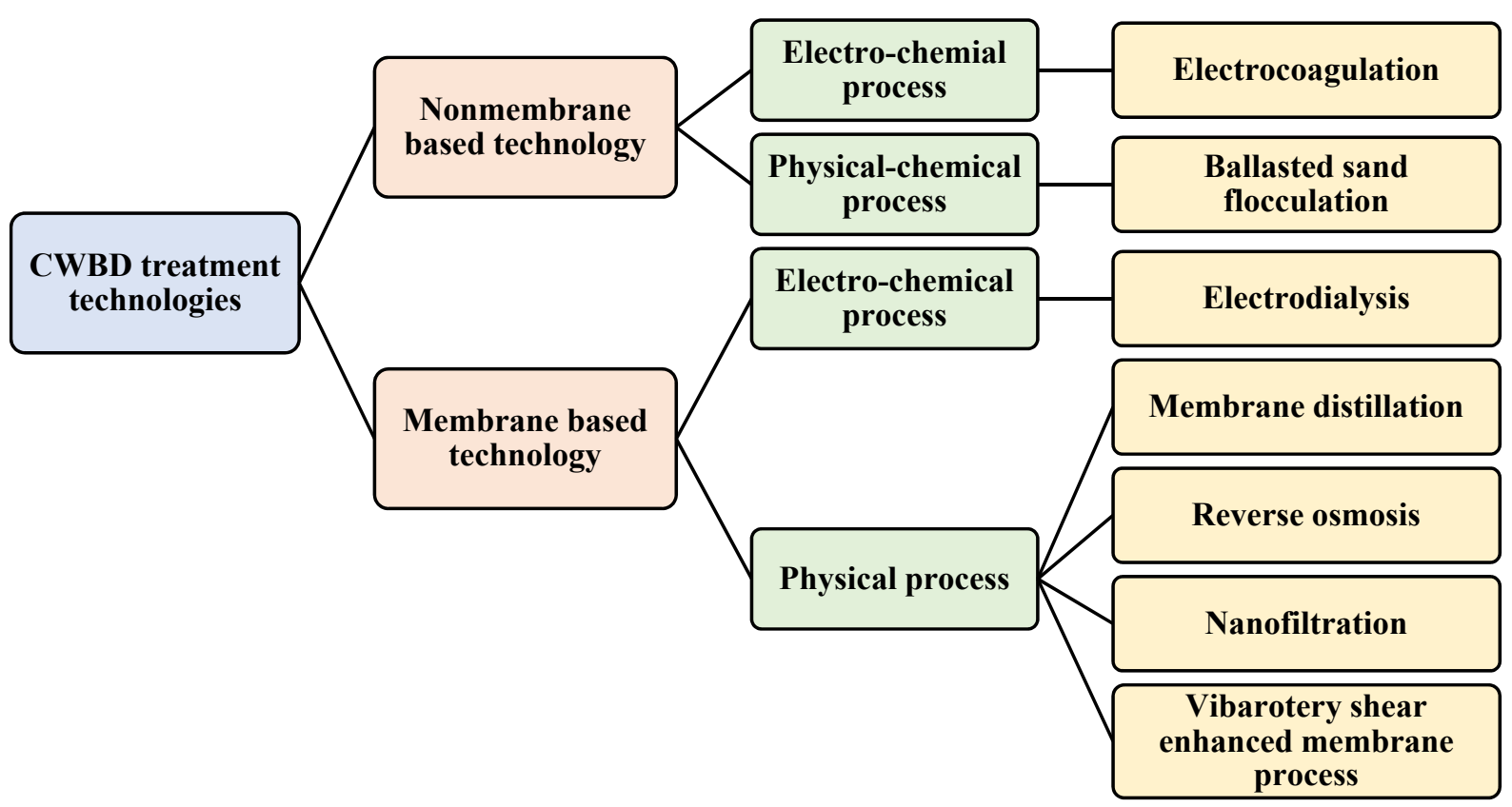

Figure 1. A summary of CWBD treatment technologies.

\subsection{Membrane-Based Technologies}

Membrane-based technologies are used to separate contaminants out of various streams such as wastewater. These processes do not require the addition of chemicals, have relatively low energy, and can be used and operated easily [33]. The principle of membrane processes is mainly based on the semi-permeable membranes that act as a filter that allow water to flow through and catch other contaminants. Substances can penetrate through the membrane under certain conditions, such as high pressure and the presence of electric potential [33]. Although the working principle is common between the membrane technologies, several differences make these technologies unique; major differences are highlighted in the following sections for each process.

\subsubsection{Electrodialysis Process (ED)}

The electrodialysis process for treating cooling water blowdown is an electrochemical [1] and membrane-based process. Ions in this process are transported and separated selectively by electrical field across several ion-exchange membranes [34]. At the end of the process, the concentration of ions increases in the concentrate compartment and decreases in the dilute compartment [1]. Further information about ED in the food, nutraceutical, beverage industries, as well as other industrial and municipal wastewater industries and designs, are covered within References [34-36]. The authors of [1] reported the usage of the ED process for the treatment and removal of TDS and other contaminants from CWBD efficiently. Major outcomes showed the ability of ED in a two-chambered cell to reduce TDS by $91.3 \%, 84.6 \%, 83.7 \%$, and $93.4 \%$, for trials $1,2,3$, and 4 , respectively. Additionally, ED had the ability to reduce the sulfate content in CWBD by $96 \%$ for each sample; reduce chloride for all samples by $91.9 \%$; and an average removal of sodium and calcium $93.8 \%$ and $95.7 \%$, respectively.

\subsubsection{Membrane or Thermal Membrane Distillation (MD or TMD)}

Membrane distillation is another membrane-based separation and physical technology used for the treatment of solutions that contain mainly water, such as CWBD, as studied by $[37,38]$. In MD, there is a direct contact between the aqueous solution and the microporous membrane, which is hydrophobic, at least from one side of that membrane [39]. MD is a thermally driven membrane [37], wherein the temperature difference between the two sides of the membrane induces a partial pressure gradient that leads to mass transfer of 
molecules through the pores of the membrane [37-39]. More well represented and reviewed details about this process can be found in the following papers: [37-45]. Generally, MD can treat many wastewater streams such as CWBD and water effluent from the process. For CWBD treatment, MD can utilize the waste heat from cooling towers in the process to create the temperature and pressure gradient as the driving force for the separation $[37,38]$.

\subsubsection{Reverse Osmosis ( $\mathrm{RO})$}

Reverse osmosis ( $\mathrm{RO}$ ) is one of the commonly used membrane-based technologies to treat wastewater stream effluent from different industrial processes as well as other sectors. This technology can be implemented to treat CWBD and usually requires a pre-treatment process to limit and reduce the membrane fouling as reviewed and studied in the literature $[11,26,46-49]$. Scaling phenomena occur when the dissolved salts become concentrated due to the extraction of clean water, which can lead to fouling of RO membrane. Examples of scaling constituents present in CWBD are calcium and magnesium hardness, fluoride, bicarbonates, barium, sulfates, strontium, silicate, and phosphates. As previously mentioned, pretreatment is one of the scaling control strategies in the RO process. In addition, conventional techniques such as the addition of scale inhibitors (e.g., polyacrylamide (PAM), polyacrylic acid (PAA), and polymaleic anhydride), or by adjusting the operational parameters such as time. Recently, novel techniques have been developed to control the scaling in $\mathrm{RO}$ process such as nanofiltration and feed flow reversal. $\mathrm{RO}$ is a membrane desalination process driven by pressure, where a semipermeable membrane is used to allow only water to penetrate, leaving behind the dissolved ions and salt. Several pre-treatment processes have been reviewed by Ahmed et al. [11]; they include constructed wetlands, coagulation settling and filtration, microfiltration, powdered activated carbon (PAC) adsorption, and ultrafiltration (UF). The result out of the review showed that physio-chemical processes are practical for CWBD pre-treatment. Among the prefiltration processes, ultrafiltration is the most popular option; however, MF can be a better alternative to UF. Löwenberg et al. [26] conducted experiments and investigated the suitability of using PAC adsorption, coagulation, and UF as pre-treatment processes before RO for the treatment CWBD. The main output of this study showed that coupling PAC with UF is the best combination as a pre-treatment process to enhance the performance of the $\mathrm{RO}$ process. In another study, Hossein et al. [47] investigated the suitability of coagulation-filtration and UF as pre-treatment processes before nanofiltration (NF) and RO to treat CWBD. Results showed that both pre-treatment processes are efficient; however, UF may face fouling, and hence it requires a pre-treatment to overcome this issue.

\subsubsection{Nanofiltration (NF)}

Nanofiltration is a membrane-based technology used for the treatment of waters, such as desalination of brackish water and seawater. Moreover, it can treat wastewater streams from different applications such as textile, industrial, and pharmaceutical [50]. With a pore size between 1 to $10 \mathrm{~nm}$, small ions and organic substrates can be selectively removed by NF with low consumption of energy [50-52]. Olariu et al. [20] mentioned that the pore size of NF membrane could be between 1 to $10 \mathrm{~nm}$, which is capable of removing large organics, as well as monovalent and divalent ions. Further details about the process, the working mechanism of NF technology, and other information are well presented in the following papers: [50-53]. NF can be implemented in industries where CWBD water requires treatment. Olariu et al. [20] used the NF process as a treatment process of CWBD water in a pilot plant with other pre-treatment steps. Results showed that around 97\% of salts were rejected. In addition, Hossien et al. [47] experimented as a part of their study on the effect of using RO or NF as a post-treatment process. The results showed that both were applicable and produced high-quality water for reuse. 


\subsubsection{Vibratory Sheared Enhanced Membrane Process (VSEP)}

VSEP is one of the emerging membrane-based separation technologies used for the treatment of wastewater streams discharged from different applications. VSEP is similar to conventional membrane technologies; however, the membrane is mechanically vibrated for better removal efficiency of contaminants as well as reducing fouling problems associated with membrane processes due to the high sheared stress applied on the surface of the membrane [54,55]. VSEP can be used in various applications, such as for the treatment of brine as discussed by Balasubramanian et al. [56] and the treatment of landfill leachates as experimented by Zouboulis et al. [57]. The use of VSEP is for the treatment of CWBD water streams for water recovery and reuse, as well as for reducing the volume of CWBD streams.

\subsection{Non-Membrane Based-Technologies}

\subsubsection{Electrocoagulation Process (EC)}

Electrocoagulation is a non-membrane-based and electrochemical separation process used to remove different pollutants by applying chemical and physical mechanisms [58-60]. The supplied electricity to the system can destabilize emulsified, dissolved, or suspended pollutants and contaminants in an aqueous medium [58]. This process can be used in many industrial applications to treat the effluents out of the processes, such as manufacturing [61] and petrochemical industries [62]. It is used to remove contaminants such as hardness ions [63], nickel [64], iron [65], chromium [66], fluoride [67], and phosphate [68]. More descriptions of the mechanisms used in the process and the reaction are available in the following references: [58,69-72]. Recently, El-khateeb et al. [4] studied the possibility of using magnesium rod-electrodes in the EC process to treat the effluent stream blowdown from cooling towers. Results showed that the system was able to remove hardness ions and silica with efficiencies of 51.80 and $93.70 \%$, respectively. Other studies have shown supporting evidence that the use of the EC process to treat CWBD is effective $[4,5,73]$.

\subsubsection{Ballasted Sand Flocculation Process (BSF)}

BSF is one of the physical-chemical non-membrane-based processes used for the treatment of water and wastewater streams effluent from various sectors. It is capable of removing many contaminants, such as total suspended solids TSS, and a wide range of heavy metals, as well as reducing COD and BOD indicators [74]. BSF can be used for the treatment of urban run-off water [75], stormwater run-off [76], CWBD [77], and others. Three main processes followed in BSF technology include injection of micro-sand, coagulant, and polymer to the system, followed by a maturation process, and finally settling the mixture and separation [74]. Further details and experimental work about BSF can be found in the following references: [74-76,78,79].

\section{Evaluation of CWBD Water Treatment Technologies}

Implementing one of the previously reviewed technologies for the treatment of CWBD water is highly applicable. However, considering the most suitable, green, sustainable, and highest performance technology is the main objective targeted by industries. Before implementation, screening and evaluating suitable technologies is necessary and requires a clear definition of the performance criteria. In this section, key criteria are used to compare and assess the treatment systems for CWBD; Table 2 shows a summary of the findings. The criteria considered are the scale of the process; maintenance requirements; chemical additive requirements for the system; energy consumption; permeate (effluent) quality; sludge characteristics; and, most importantly, the ability to remove CWBD contaminants and cost. All of these criteria are discussed and evaluated in this section.

Most of the seven technologies presented earlier were implemented in different scales, including laboratory, pilot, and commercial or industrial. However, ED and RO processes are considered one of the most established and well-known processes and are widely used [80-83]. NF, VSEP, BSF, and EC can be considered as emerging technologies, and this is due to limitations in their performance and cost, as is highlighted below. 
Required maintenance for a system is often a factor that the industry considers. This criterion is impacted by the material used in the system, the number of moving parts, availability of membranes and associated fouling problems, and many others. EC technology requires maintenance mainly related to the periodic replacements of the electrodes used in the system [58]. It is considered a low maintenance system as compared to membrane-based technologies such as RO, ED, and NF. As some require high operating pressure and have issues with fouling. ED process has a longer membrane lifetime, and therefore maintenance will be lower than RO process [84]. Applying a pre-treatment process ahead to these technologies can reduce the fouling problems, consequently reducing the maintenance requirements. MD and VSEP processes require low maintenance; the latter is designed with a vibrating membrane to minimize fouling. The needed maintenance by VSEP is mainly associated with the few moving parts in the system [85].

The use of chemical additives in the process is an inherent part of some water treatment systems such as ED, RO, MD, and NF. Moreover, often, chemical treatment is required for the regeneration and cleaning of membrane-based processes. In the studied water treatment systems, BSF technology requires a high quantity of chemical dosages. The optimum values are $5-150 \mathrm{mg} / \mathrm{L}$ of alum, $40-190 \mathrm{mg} / \mathrm{L}$ of $\mathrm{FeCl}_{3}$ (ferric chloride), $0.3-1 \mathrm{mg} / \mathrm{L}$ of polymer, and $3-12 \mathrm{mg} / \mathrm{L}$ of sand.

Energy requirements and consumption is critical aspect that affects the operational cost of the process directly impacts on the environment in terms of emission. Electricity is the main source of power used in these processes; however, in MD, most of the consumed power in the process is in terms of heat, with a small amount of electricity for running pumps [37]. Both $\mathrm{NF}\left(0.3-1 \mathrm{kWh} / \mathrm{m}^{3}\right)$ [86] and ED processes (depending on the level of TDS) require less energy compared to the RO process $\left(1.5-6 \mathrm{kWhe} / \mathrm{m}^{3}\right)[87,88]$, mainly due to lower pressure requirement $[89,90]$. However, increased energy requirements are observed for ED for influent streams with higher salt content [91]. VSEP requires higher energy than $\mathrm{RO}$ process mainly due to the need for intense shear requirements on the membrane; under the same conditions, at TDS of $500 \mathrm{mg} / \mathrm{L}$, motor/pump efficiency of $85 \%$, and feed water recovery of $75 \%$, the energy required by $\mathrm{RO}$ is $0.7 \mathrm{kWh} / \mathrm{m}^{3}$. In contrast, VSEP requires $2.1 \mathrm{kWh} / \mathrm{m}^{3}$. In the BSF process, hydro-cyclone is used for the separation and recirculation of micro-sand back to the process, which requires high-pressure input, and consequently higher energy consumption [92]. Finally, for EC, the operation of the process depends mainly on a continuous source of electricity. However, many studies were conducted to reduce the consumption of power by using more effective electrodes or changing their configurations for lower energy, as indicated in Table 2. The alternative available for EC is to consider using of a renewable energy source such as a solar system to reduce environmental impacts from energy consumption [93].

The quality and characterization of the permeate stream (treated) and the sludge or concentrated stream (rejected with contaminants) are key factors in selecting a suitable wastewater treatment technology. EC process produces high-quality effluent with low content of TDS and has neither color nor odor. EC system removes hardness and silica ions with different types of electrodes such as $\mathrm{Zn}, \mathrm{Fe}$, and $\mathrm{Al}$ electrodes with a removal efficiency of $38.63 \%$ and $95.62 \%, 36.99 \%$ and $98.93 \%$, and $55.36 \%$ and $99.54 \%$ for the total hardness and silica ions, respectively. Although the water quality effluent from RO process is high, ED process has a higher recovery rate in comparison. For MD process, low recovery or flux of water is produced as compared to RO process, but the salt concentration in permeate is approximately zero. NF process has stable flowrate and clean permeate as in Table 2; in fact, many industries are using the technology and some are replacing their RO process [50]. BSF is comparable to conventional processes, e.g., RO and ED, and in some cases outperforms others in terms of permeate quality [74]. VSEP is the only technology that produces a permeate stream free of solids in comparison to the studied alternatives. 
Table 2. Evaluation of the treatment technologies according to the selected criteria.

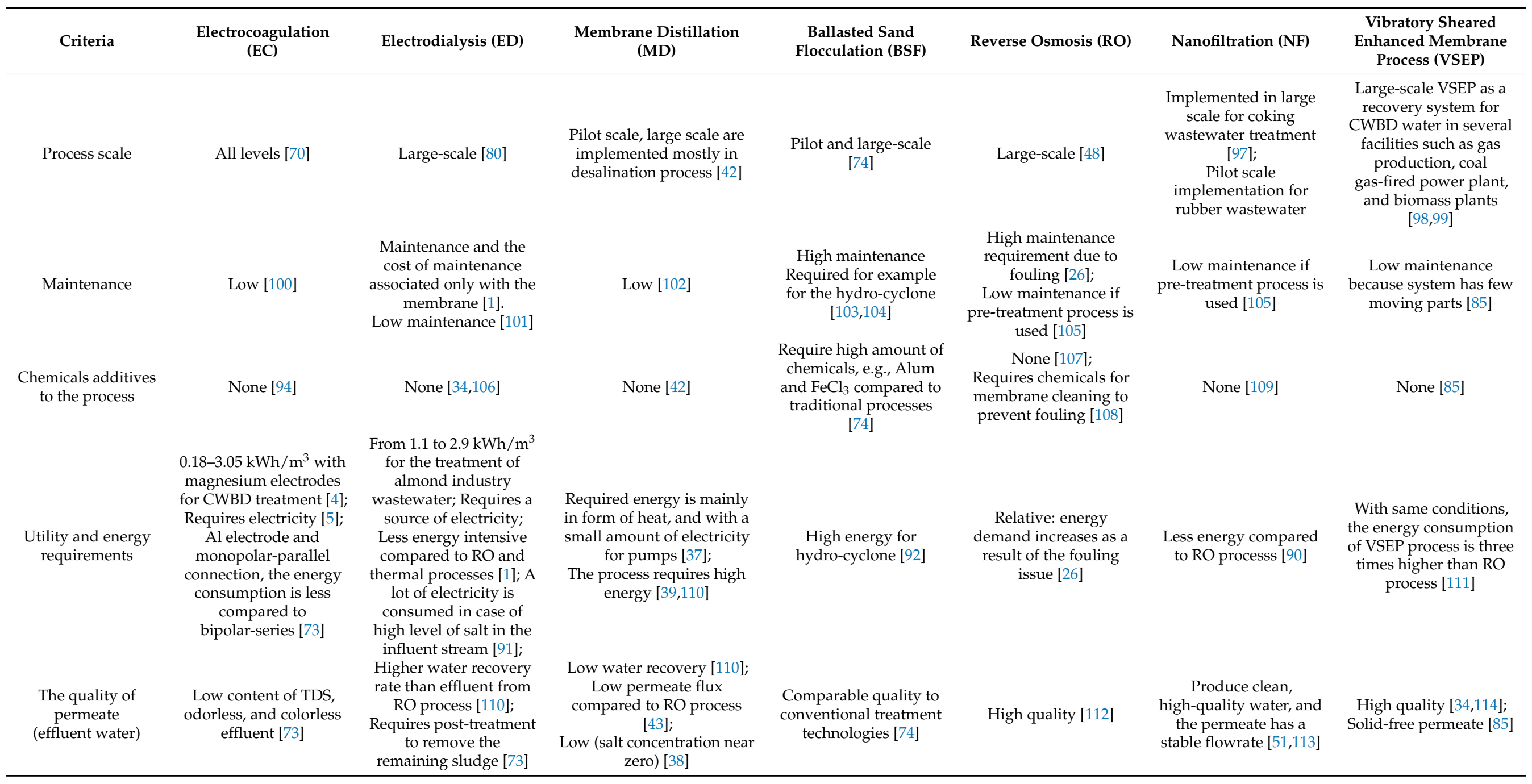


Table 2. Cont.

\begin{tabular}{|c|c|c|c|c|c|c|c|}
\hline Criteria & $\begin{array}{l}\text { Electrocoagulation } \\
\text { (EC) }\end{array}$ & Electrodialysis (ED) & $\begin{array}{l}\text { Membrane Distillation } \\
\text { (MD) }\end{array}$ & $\begin{array}{c}\text { Ballasted Sand } \\
\text { Flocculation (BSF) }\end{array}$ & Reverse Osmosis (RO) & Nanofiltration (NF) & $\begin{array}{l}\text { Vibratory Sheared } \\
\text { Enhanced Membrane } \\
\text { Process (VSEP) }\end{array}$ \\
\hline $\begin{array}{l}\text { The sludge quality } \\
\text { (rejection) }\end{array}$ & $\begin{array}{c}\text { Low sludge discharge, } \\
\text { stable, and non-toxic } \\
\text { [71,94]; } \\
\text { Sludge contains mainly } \\
\text { metallic } \\
\text { oxides/hydroxides [73] }\end{array}$ & $\begin{array}{l}\text { High sludge discharge } \\
\text { [73] }\end{array}$ & $\begin{array}{l}\text { Non-volatile compounds, } \\
\text { macromolecules, and } \\
\text { inorganic ions are all highly } \\
\text { rejected from the water } \\
\text { stream to the sludge with } \\
(99-100 \%) \text { and the } \\
\text { separation theoretically can } \\
\text { reach } 100 \% \text { [115-117] }\end{array}$ & $\begin{array}{c}\text { Flocs easily eliminated } \\
\text { by settling [74]; } \\
\text { Sludge layer is distinct, } \\
\text { clear, and supernatant } \\
\text { [78] }\end{array}$ & $\begin{array}{l}\text { A concentrated stream } \\
\text { with high salinity [118] }\end{array}$ & $\begin{array}{c}\text { Low discharge sludge } \\
\text { [109]; } \\
\text { Retentate } \\
\text { concentrations lower } \\
\text { than RO for low value } \\
\text { salts in the influent } \\
\text { stream [109]; } \\
\text { Rejection efficacy } \\
\text { altered when fouling } \\
\text { occurs [50] }\end{array}$ & $\begin{array}{l}\text { Concentrated waste } \\
\text { stream with } 30 \text { to } 35 \% \\
\text { total solids (higher than } \\
\text { the feed) }[95,96]\end{array}$ \\
\hline
\end{tabular}


In terms of sludge or the concentrated stream produced from these technologies, EC has non-toxic and low amounts of sludge with no brine formation compared to the membrane, ion-exchange, and conventional technologies [94]. On the other hand, ED produces a high amount of sludge and RO has a highly saline concentrated stream. The discharged volume and the retentate concentrations of NF process are lower as compared to RO process. For BSF process, the generated flocs can be easily eliminated. VSEP concentrated stream contains a high amount of salts (30-35\%) compared to the process influent $[95,96]$. Finally, the MD process rejects various types of contaminants with a very high percentage close to $100 \%$ to form a concentrated stream of non-volatile compounds, macromolecules, and inorganic ions.

Contaminant removal effectiveness of the technology is a top criterion in selecting the CWBD treatment system. The literature has presented the removal and treatment capability of EC, ED, and MD processes for several contaminates in CWBD stream. It is important to clarify that the conducted experiments by EC and ED processes analyzed the removal or reducing levels of targeted contaminants such as magnesium, calcium, and silica for EC and reducing the level of TDS for ED. Hence, the results presented in Table 3 reflect the published data on the ability of the technology to remove contaminants and do not reflect the technology's ability to remove all the other contaminants in Table 1. As shown in Table 3, all three methods (ED, EC, MD) can remove major common contaminants in CWBD streams such as calcium, magnesium, chloride, and sulphate. TDS, which is considered one of the crucial contaminants of concern, can be removed by both EC and ED processes. According to the literature, only EC is reported to remove silica, zinc, and phosphate, and only MD is reported to remove copper and manganese. Additionally, ED can remove bromides and fluorine ions from CWBD water. Moreover, sodium and potassium can be removed using ED and MD, but Fe can be removed only by EC and MD. The removal efficiency differs for each technology, and it depends on the concentration of the feed and the operating conditions as reported by the authors of that literature.

Table 3. The contaminants that can be removed by CWBD treatment technologies.

\begin{tabular}{cccc}
\hline Contaminants & \multicolumn{3}{c}{ CWBD Treatment Technologies } \\
\cline { 2 - 5 } & EC [4] & ED [1] & MD [37] \\
\hline Total dissolved Solids & $\sqrt{ }$ & $\sqrt{ }$ & \\
(TDS) & $\sqrt{ }$ & $\sqrt{ }$ & $\sqrt{ }$ \\
Calcium $\left(\mathrm{Ca}^{2+}\right)$ & $\sqrt{ }$ & $\sqrt{ }$ & \\
Magnesium $\left(\mathrm{Mg}^{2+}\right)$ & $\sqrt{ }$ & $\sqrt{ }$ & \\
Silica $\left(\mathrm{SiO}_{2}\right)$ & $\sqrt{ }$ & & $\sqrt{ }$ \\
Chloride $\left(\mathrm{Cl}^{-}\right)$ & $\sqrt{ }$ & & $\sqrt{ }$ \\
Zinc $\left(\mathrm{Zn}^{2+}\right)$ & $\sqrt{ }$ & $\sqrt{ }$ & \\
Phosphate $\left(\mathrm{PO}_{4}^{3-}\right)$ & $\sqrt{ }$ & & $\sqrt{ }$ \\
Iron $\left(\mathrm{Fe}^{2+}\right)$ & $\sqrt{ }$ & $\sqrt{ }$ & $\sqrt{ }$ \\
Sulphate $\left(\mathrm{SO}_{4}^{2-}\right)$ & & $\sqrt{ }$ & \\
Aluminium $\left(\mathrm{Al}^{3+}\right)$ & & & $\sqrt{ }$ \\
Barium $\left(\mathrm{Ba}^{2+}\right)$ & & $\sqrt{ }$ & \\
Potassium $\left(\mathrm{K}^{+}\right)$ & & $\sqrt{ }$ & \\
Sodium $\left(\mathrm{Na}^{+}\right)$ & & & \\
Copper $\left(\mathrm{Cu}^{2+}\right.$ & & & \\
Strontium $\left(\mathrm{Sr}^{2+}\right)$ & & & \\
Bromide $\left(\mathrm{Br}^{-}\right)$ & & & \\
Fluorine $(\mathrm{F})$ & & & \\
Manganese $\left(\mathrm{Mn}^{2+}\right)$ & & & \\
Nitrate $\left(\mathrm{NO}^{3-}\right)$ & & & \\
\hline
\end{tabular}

The applicability for the treatment of CWBD streams using BSF, RO, NF, and VSEP technologies has been reported in the literature, even though there is a lack of published experimental data related to the specific contaminants that can be removed by these 
systems [11,26,47,99]. Reference [77] discussed the fact that the BSF process can be used for the CWBD effluent treatment, and Ahmed et al. [11] studied the potential for CWBD water recovery by reverse osmosis, discussing the fouling parameters as well as implemented various pre-treatment processes ahead of RO. Löwenberg et al. [26] conducted experimental work to evaluate various pre-treatment processes before applying $\mathrm{RO}$ as the final treatment step for CWBD. For NF and RO, Hossein et al. [47] also studied reusing CWBD after recovering it by $\mathrm{NF}$ or $\mathrm{RO}$ processes and investigated various pre-treatment steps to control fouling problems. As an emerging technology, VSEP technology website [99] reported that this process could reduce the volume of CWBD stream for either disposal or recycling it back to the cooling towers on the basis of pilot plant data.

In general, the reviewed technologies can remove a wide range of contaminants from many water and wastewater streams. For example, $\mathrm{RO}$ can remove almost all contaminants of concern such as TDS, ammonia (as N), iron, lead, nitrate (as N), sulphate, chloride, phosphate, calcium, magnesium, and others [119,120]. BSF can remove TP, TSS, iron, lead, zinc, etc. [74]. NF process can remove iron, manganese, calcium, magnesium, fluoride, sulphate, and more [121]. For VSEP technology, TDS, chloride, sulfate, calcium, magnesium, fluoride, nitrate, and others can be removed [111].

Conducting a cost analysis is another criterion to evaluate the technologies since the economic aspect should be justified and viable. Table 4 summarizes the operational and capital costs of the treatment technologies on the basis of color-coding. EC and MD technologies have low capital and operating costs, and consequently, lower total costs. The operating cost of EC process is mainly attributed to the fact that the power consumption in the form of electricity is high since it is one of the major requirements for the system to run and remove contaminants. For MD technology, it contains various designs and configurations for that the cost differs. For example, Air Gap membrane distillation (AGMD) is considered an effective method compared to others as it has how operational and maintenance costs. For the capital cost, MD generally has a lower capital cost than reverse osmosis, and such lower costs make the total cost low. Moving to RO and VSEP technologies requires high capital and operating costs, hence relatively high overall total cost. The high operational cost of $\mathrm{RO}$ process can be attributed to the fouling problems that shorten the membrane's lifetime and requires replacing it; moreover, the RO process operates at high pressure, which consumes high energy, leading to a higher cost of operation. For the emerging technology VSEP, the high operational cost is because of the high energy requirements to generate shear and vibrating the membrane. Subramani et al. [111] reported out of the conducted study that the consumption of energy by VSEP process is three times $\left(2.1 \mathrm{kWh} / \mathrm{m}^{3}\right)$ higher than $\mathrm{RO}$ process $\left(0.7 \mathrm{kWh} / \mathrm{m}^{3}\right)$, reaching more than 10 years, all of which contribute to lowering the operational cost [84]. However, ED has a high capital cost, which makes the total cost at a moderate level. The BSF process has a higher operational cost than conventional or traditional processes, and this can be said to be mainly due to the high dosages of chemicals needed for the process [74]. On the other hand, for the capital cost, BSF requires smaller sedimentation units because it has high settling rates; additionally, the BSF requires less land size, and hence lower capital cost, leading to a moderate total cost. For NF, which is another membrane-based technology, the process operates at low pressure and requires less energy consumption; hence, it has low operational costs. However, for the capital cost, the implementation of NF technology at large scales causes the capital cost to be high, which limits NF applications for treatment purposes in industries and makes the total cost relatively moderate. In the end, the total cost depends on many factors such as the size of the plant, the concentration of the influent stream, and the maintenance and energy requirements. Reducing the total cost can be done by enhancing the treatment technology by using efficient material with low cost and by utilizing renewable sources of energy instead of a direct source of power. 
Table 4. Cost analysis of CWBD treatment technologies.

\begin{tabular}{|c|c|c|c|c|c|c|c|}
\hline & EC & ED & MD & BSF & RO & NF & VSEP \\
\hline \multicolumn{8}{|c|}{ Operational cost } \\
\hline \multicolumn{8}{|l|}{ Capital cost } \\
\hline \multicolumn{8}{|l|}{ Total cost } \\
\hline References & {$[5,122,123]$} & {$[122,124]$} & {$[44,125]$} & {$[74,126]$} & {$[48,122]$} & {$[127,128]$} & [129] \\
\hline \multirow[t]{4}{*}{ Color coding } & Meaning & & & & & & \\
\hline & Low & & & & & & \\
\hline & Moderate & & & & & & \\
\hline & High & & & & & & \\
\hline
\end{tabular}

\section{Regulations of Wastewater Effluent from Industries}

CWBD is considered a wastewater stream discharged from cooling towers into the marine environment or sewage treatment plants, or reused in applications such as irrigation. Each of these discharge points has certain regulations and permissible limits for the water contaminants; the constraints are there to avoid negative and long-term consequences on the environment and society. Table 5 shows standards regulated by the United States Environmental Protection Agency (EPA) and some GCC agencies. Each agency's standards vary depending on the endpoint or application, and there is a noticeable difference in limits between agencies for the application. For example, the concentration of the pollutant by EPA for irrigation purposes differ only slightly from the one regulated by Qatar for boron, cadmium, cobalt, manganese, and zinc. However, the concentrations of aluminum, fluoride, iron, and lead are considerably different when both standards are compared. One major reason behind these differences is attributed to the type of soil; in Qatar, as in many other GCC countries such as the UAE, the soil is sandy, and this plays a role in trace metal adsorption and translocation in the soil-plant environment. The accumulation of heavy metals such as $\mathrm{Zn}, \mathrm{Cd}, \mathrm{Cu}, \mathrm{Cr}, \mathrm{Fe}$, and $\mathrm{Pb}$ in the soil will be minimal because of the high infiltration of the sandy soil, deep percolation losses, and high evaporation rate [130].

Discharging the treated wastewater into marine environments as compared to irrigation has more stringent levels for some contaminants such as fluoride, TDS, and sulphate in addition to the pollutant indicators such as COD. This can be because of the negative direct impacts of these contaminants on living creatures such as fishes, flora, and fauna [18]. For other contaminants such as nickel, zinc, chromium, cobalt, and manganese, the standards for irrigation are more stringent than for the marine environment. This can be attributed to the fact the levels are already small, and the concentrations of these pollutants will be further diluted in the marine compared to irrigation. Comparing the standards of both the UAE and Qatar, one can notice that for some contaminants such as boron, cobalt, nickel, and zinc, Qatar permits slightly higher concentrations than the UAE and lower concentrations for other contaminants such as aluminum, fluoride, and iron. For Oman, almost all regulated contaminant levels are the same as the UAE, except for cyanide, phosphate, zinc, and cadmium. In general, GCC countries have comparable limits on contaminants concentrations. Using diffusers with single or multi ports, and the depth of these diffusers determines the level of dilution for the discharged pollutants [131]. It is also known that discharging using diffusers, in general, dilutes the contaminants more and faster compared to single-point discharges [131]. The noted similarities of regulations between GCC countries for discharging to marine life can be mainly attributed to the fact that countries have limited freshwater resources, and protecting the marine environment is of higher priority. 
Table 5. Standards and regulations of treated wastewater streams for discharging or reusing.

\begin{tabular}{|c|c|c|c|c|c|c|c|}
\hline \multirow[b]{2}{*}{ Parameter } & \multicolumn{2}{|c|}{$\begin{array}{c}\text { Standards of Water and Wastewater } \\
\text { for Irrigation }\end{array}$} & \multicolumn{3}{|c|}{ Standards of Discharging into Marine } & \multicolumn{2}{|c|}{$\begin{array}{c}\text { Standards of Discharging Liquid Waste to } \\
\text { Public Foul Sewage Networks }\end{array}$} \\
\hline & $\begin{array}{c}\text { EPA } \\
\text { Irrigation ppm } \\
{[132]}\end{array}$ & $\begin{array}{c}\text { Qatar } \\
\text { Irrigation ppm } \\
{[133]}\end{array}$ & $\begin{array}{c}\text { Qatar } \\
\text { Discharges into } \\
\text { Water Environment } \\
\text { or Marine ppm [133] }\end{array}$ & $\begin{array}{c}\text { UAE } \\
\text { Discharges to } \\
\text { Marine at Point of } \\
\text { Discharge ppm [134] }\end{array}$ & $\begin{array}{l}\text { Oman } \\
\text { Discharges to } \\
\text { Marine } \\
\text { ppm [135] }\end{array}$ & $\begin{array}{c}\text { Qatar } \\
\text { Discharged Liquid } \\
\text { Waste for Treatment } \\
\text { by Public Sewage } \\
\text { Work ppm [133] }\end{array}$ & $\begin{array}{c}\text { Qatar } \\
\text { Industrial Effluent } \\
\text { Discharged to } \\
\text { Sewers ppm [133] }\end{array}$ \\
\hline Aluminium & 5.0 & 15 & 3 & 20 & & 30 & - \\
\hline Arsenic & 0.10 & 0.1 & - & 0.05 & 0.05 & 5 & 5 \\
\hline Boron & 0.75 & 1.5 & 1.5 & 1 & & - & - \\
\hline Cadmium & 0.01 & 0.05 & 0.05 & 0.05 & 0.50 & 2 & 10 \\
\hline Chromium & 0.1 & 0.01 & 0.2 & 0.2 & & 5 & 2 \\
\hline Cobalt & 0.05 & 0.2 & 2 & 0.2 & & - & - \\
\hline Copper & 0.2 & 0.2 & 0.5 & 0.5 & 0.50 & 5 & 4 \\
\hline Fluoride & 1 & 15 & 1 & 10 & & - & - \\
\hline Iron & 5 & 1 & 1 & 2 & 2.0 & 25 & - \\
\hline Lead & 5 & 0.1 & 0.1 & 0.1 & 0.10 & 5 & 5 \\
\hline Lithium & 2.5 & - & - & - & & - & - \\
\hline Molybdenum & 0.01 & - & - & - & & - & - \\
\hline Nickel & 0.2 & 0.2 & 0.5 & 0.1 & 0.10 & 5 & - \\
\hline Selenium & 0.02 & - & 0.02 & 0.02 & 0.02 & - & - \\
\hline Vanadium & 0.1 & - & - & - & & - & - \\
\hline Zinc & 2 & 0.5 & 2 & 0.5 & 0.10 & 10 & 4 \\
\hline TDS & - & 2000 & 1500 & - & & 4000 & - \\
\hline Sulphate & - & 400 & 0.1 & - & & 1000 & 1000 \\
\hline Phosphate as $\mathrm{P}\left(\mathrm{PO}_{4}{ }^{-3}\right)$ & - & 30 & 2 & 2 & 0.10 & - & - \\
\hline Ammonia as $\mathrm{N}$ & - & - & 3 & 2 & & - & - \\
\hline Chlorine residual & - & 0.1 & 0.05 & - & & - & - \\
\hline Cyanide (total) & - & - & 0.1 & 0.05 & 0.10 & 1 & 1 \\
\hline Nitrates & - & - & - & 30 & & - & - \\
\hline COD & - & 150 & 100 & 100 & & 3000 & 3000 \\
\hline BOD5 & - & 10 & 50 & 30 & 30 & 1000 & - \\
\hline Total organic carbon (TOC) & - & - & - & 75 & & 1000 & - \\
\hline
\end{tabular}


Discharging the effluent wastewater from industries into sewage treatment plants is one of the management practices performed by many countries as it can treat various wastewater streams. However, caution should be taken regarding the concentration of the contaminants influent to sewage systems because some are designed for certain types of pollutants and at a specific limited range of concentration, as it may cause various harmful consequences as previously mentioned in Section 2. In Table 5, it is noted that the standard concentrations of contaminants influent to sewage treatment plants or sewer systems have higher tolerance compared to irrigation and marine discharging, especially in terms of TDS as well as the pollutant indicators such as BOD and COD. This is expected as treatment plants are designed to handle high concentration of contaminants that cannot be discharged to natural environments.

Generally, treatment and management of CWBD is necessary, and the suitable options in terms of treatment depend on desired effluent quality. This quality is dictated by the endpoint of discharge or treated water application as regulated by standards of the country, as has been presented and discussed in this work.

\section{Conclusions}

CWBD is a very concentrated wastewater stream with various types of contaminants that can affect the entire ecosystem if it is not handled and treated properly. Various processes can be implemented to treat CWBD stream. Some of these technologies are already established, such as RO, ED, MD, and BSF, while others are emerging, such as EC, VSEP, and NF. In terms of choosing the best technology, being green and environmentally friendly are amongst the key considerations, besides the cost and the treatment performance. On the basis of the performed evaluation, membrane-based technologies result in high-quality treated water, but some of them, such as NF and $\mathrm{RO}$, are prone to fouling problems, resulting in higher maintenance requirements. Additionally, EC and VSEP also produce high-quality permeate; however, they are energy-intensive processes. BSF is the only process that requires a large quantity of chemicals as a part of the system. For the most cost-effective technologies, EC and MD should be considered; ED and NF can also be considered if a pre-treatment step is available. EC has a high treatment performance $(\approx 99.54 \%$ in terms of silica ions) compared to UF membrane method (reduction of $65 \%$ of colloidal silica). For the treatment of contaminants, $\mathrm{ED}, \mathrm{MD}$, and EC processes treat a wide range of contaminants in CWBD. However, for a fair comparison, further studies should be conducted on the ability of RO, BSF, VSEP, and NF to treat CWBD contaminants to obtain a more reasonable conclusion. Regarding energy consumption, both EC 0.18-3.05 kWh $/ \mathrm{m}^{3}$ and VSEP $\sim 2.1 \mathrm{kWh} / \mathrm{m}^{3}$ technologies have high energy demand, and this limits their implementation for large-scale applications unless renewable energy sources are used. When it comes to the recovery and reusing of treated wastewater or even discharging it to the marine environment, standards and regulations must be obeyed. Overall, the treatment of CWBD water should be further studied and considered since research related to this topic is limited. Treatment and reuse of CWBD can help overcome the water scarcity problem and achieve a more sustainable environment.

Funding: This research is funded by Ministry of Municipality and Environment in Qatar, Project MME contract no. P2020/1.

Institutional Review Board Statement: Not applicable.

Data Availability Statement: Not applicable.

Acknowledgments: This paper was made possible by funding from Ministry of Municipality and Environment in Qatar, Project MME contract no. P2020/1. The statements made herein are solely the responsibility of the author(s).

Conflicts of Interest: The authors declare no conflict of interest. 


$\begin{array}{ll}\text { Abbreviations } \\ \text { CWBD } & \text { Cooling water blowdown } \\ \text { RO } & \text { Reverse osmosis } \\ \text { ED } & \text { Electrodialysis } \\ \text { MD } & \text { Membrane distillation } \\ \text { EC } & \text { Electrocoagulation } \\ \text { NF } & \text { Nanofiltration } \\ \text { COD } & \text { Chemical oxygen demand } \\ \text { BOD } & \text { Biological oxygen demand } \\ \text { TDS } & \text { Total dissolved solids } \\ \text { TSS } & \text { Total suspended solids } \\ \text { BSF } & \text { Ballasted sand flocculation } \\ \text { VSEP } & \text { Vibratory shear enhanced membrane process }\end{array}$

\section{References}

1. Dhadake, Y. Treatmnet of Cooling Tower Blowdown Water Using Electrodialysis; California State University: Long Beach, CA, USA, 2018.

2. Afshari, F.; Dehghanpour, H. A Review Study on Cooling Towers; Types, Performance and Application. ALKU J. Sci. 2019, 1-10. Available online: https:/ / dergipark.org.tr/en/pub/alku/issue/41490/489143 (accessed on 28 November 2021).

3. Panjeshahi, M.; Ataei, A.; Gharaie, M.; Parand, R. Optimum design of cooling water systems for energy and water conservation. Chem. Eng. Res. Des. 2009, 87, 200-209. [CrossRef]

4. Abdel-Shafy, H.I.; Shoeib, M.A.; El-Khateeb, M.A.; Youssef, A.O.; Hafez, O.M. Electrochemical treatment of industrial cooling tower blowdown water using magnesium-rod electrode. Water Resour. Ind. 2020, 23, 100121. [CrossRef]

5. Hafez, O.M.; Shoeib, M.; El-Khateeb, M.A.; Abdel-Shafy, H.; Youssef, A.O. Removal of scale forming species from cooling tower blowdown water by electrocoagulation using different electrodes. Chem. Eng. Res. Des. 2018, 136, 347-357. [CrossRef]

6. Saha, P.; Bruning, H.; Wagner, T.V.; Rijnaarts, H.H. Removal of organic compounds from cooling tower blowdown by electrochemical oxidation: Role of electrodes and operational parameters. Chemosphere 2020, 259, 127491. [CrossRef] [PubMed]

7. Saha, P.; Wagner, T.V.; Ni, J.; Langenhoff, A.A.; Bruning, H.; Rijnaarts, H.H. Cooling tower water treatment using a combination of electrochemical oxidation and constructed wetlands. Process. Saf. Environ. Prot. 2020, 144, 42-51. [CrossRef]

8. Wagner, V.T.; Parsons, J.R.; Rijnaarts, H.H.M.; de Voogt, P.; Langenhoff, A.A.M.; Wagner, T.V.; Parsons, J.R.; Rijnaarts, H.H.M.; de Voogt, P. Technology a Review on the Removal of Conditioning Chemicals from Cooling Tower Water in Constructed Wetlands. Crit. Rev. Environ. Sci. Technol. 2019, 48, 1094-1125. [CrossRef]

9. Li, X.; Wu, L.; Lu, S.; Yang, H.; Xie, W.; Zhao, H.; Zhang, Y.; Cao, X.; Tang, G.; Li, H.; et al. Treatment of cooling tower blowdown water by using adsorption-electrocatalytic oxidation: Technical performance, toxicity assessment and economic evaluation. Sep. Purif. Technol. 2020, 252, 117484. [CrossRef]

10. Stratton, C.L.; Lee, G.F. Cooling Towers and Water Quality. J. Water Pollut. Control Fed. 1975, 47, $1901-1912$.

11. Ahmed, J.; Jamal, Y.; Shujaatullah, M. Recovery of cooling tower blowdown water through reverse osmosis (RO): Review of water parameters affecting membrane fouling and pretreatment schemes. Desalin. Water Treat. 2020, 189, 9-17. [CrossRef]

12. Altman, S.J.; Jensen, R.P.; Cappelle, M.A.; Sanchez, A.L.; Everett, R.L.; Anderson, H.L.; McGrath, L.K. Membrane treatment of side-stream cooling tower water for reduction of water usage. Desalination 2012, 285, 177-183. [CrossRef]

13. Cheng, Q.; Wang, C.; Doudrick, K.; Chan, C.K. Hexavalent chromium removal using metal oxide photocatalysts. Appl. Catal. B Environ. 2015, 176-177, 740-748. [CrossRef]

14. Dickerson, B.R.; Vinyard, G.L. Effects of High Levels of Total Dissolved Solids in Walker Lake, Nevada, on Survival and Growth of Lahontan Cutthroat Trout. Trans. Am. Fish. Soc. 1999, 128, 507-515. [CrossRef]

15. Maulbetsch, J.S.; DiFilippo, M.N. Performance, Cost, and Environmental Effects of Saltwater Cooling Towers. Environmental Effects of Mining; California Energy Commission: Sacramento, CA, USA, 2010; pp. 1-356.

16. Weber-Scannell, P.K.; Duffy, L.K. Effects of Total Dissolved Solids on Aquatic Organisms: A Review of Literature and Recommendation for Salmonid Species. Am. J. Environ. Sci. 2007, 3, 1-6. [CrossRef]

17. USGS. Phosphorus and Water; USGS: Reston, VA, USA, 2016.

18. Papadopoulos, E.; Arsenos, G.; Ptochos, S.; Katsoulos, P.; Oikonomou, G.; Karatzia, M.A.; Karatzias, H. Pollutants in Wastewater Effluents Impacts. J. Hell. Vet. Med. Soc. 2014, 65, 115-120.

19. Clarke, R. Groundwater: A Threatened Resource; UNEP Environmental Library, UN Environment Programme: Nairobi, Kenya, 2002; p. 36.

20. Olariu, R. Treatment of Cooling Tower Blowdown Water. The Effect of Biodispersant on the Ultrafiltration Membrane. Master's Thesis, Delft University of Technology, Delft, The Netherlands, 2015.

21. Fendorf, S.; Michael, H.A.; van Geen, A. Spatial and Temporal Variations of Groundwater Arsenic in South and Southeast Asia. Science 2010, 328, 1123-1127. [CrossRef] [PubMed] 
22. Mccarty, K.M.; Hanh, H.T.; Kim, K.-W. Arsenic geochemistry and human health in South East Asia. Rev. Environ. Health 2011, 26, 71-78. [CrossRef] [PubMed]

23. Ashraf, S.; Abbas, F.; Ibrahim, M.; Rashid, U.; Khalid, S.; Ahmad, R.; Hakeem, K.R.; Majeed, T. Application of GIS for the identification and demarcation of selective heavy metal concentrations in the urban groundwater. J. Geogr. Sci. 2015, 25, 225-235. [CrossRef]

24. Isa, N.M.; Aris, A.Z.; Lim, W.Y.; Sulaiman, W.N.A.W.; Praveena, S.M. Evaluation of heavy metal contamination in groundwater samples from Kapas Island, Terengganu, Malaysia. Arab. J. Geosci. 2014, 7, 1087-1100. [CrossRef]

25. Galadima, A.; Garba, Z.N. Heavy Metals Pollution in Nigeria: Causes and Consequences. Elixir Pollut. 2012, 45, 7917-7922.

26. Löwenberg, J.; Baum, J.A.; Zimmermann, Y.-S.; Groot, C.; Broek, W.V.D.; Wintgens, T. Comparison of pre-treatment technologies towards improving reverse osmosis desalination of cooling tower blow down. Desalination 2015, 357, 140-149. [CrossRef]

27. Shibli, S.M.A.; Saji, V.S. Corrosion Inhibitors in Cooling Towers. Chem. Ind. Dig. 2002, 15, 74-80.

28. ChemWorld. We Sell Direct to Everyone. 2016. Available online: https:/ /www.chemworld.com/ (accessed on 28 November 2021).

29. Pereira, L.; Duarte, E.; Fragoso, R. Water Use: Recycling and Desalination for Agriculture. Encycl. Agric. Food Syst. 2014, 5, 407-424. [CrossRef]

30. Bhardwaj, R.; Sharma, R.; Handa, N.; Kaur, H.; Kaur, R.; Sirhindi, G.; Thukral, A. Prospects of Field Crops for Phytoremediation of Contaminants. In Emerging Technologies and Management of Crop Stress Tolerance; Academic Press: Cambridge, MA, USA, 2014; Volume 2, pp. 449-470.

31. Sultana, M.S.; Jolly, Y.; Yeasmin, S.; Islam, A.; Satter, S.; Tareq, S.M. Transfer of Heavy Metals and Radionuclides from Soil to Vegetables and Plants in Bangladesh. In Soil Remediation and Plants: Prospects and Challenges; Elsevier: Amsterdam, The Netherlands, 2015; pp. 331-366.

32. Fales, A.L. The Effects of Industrial Wastes on Sewage Treatment; New England Interstate Water Pollution Control Commission: Boston, MA, USA, 1970; pp. 970-985.

33. Membrane Technology; Lenntech: Delft, The Netherlands, 2020.

34. Gurreri, L.; Tamburini, A.; Cipollina, A.; Micale, G. Electrodialysis Applications in Wastewater Treatment for Environmental Protection and Resources Recovery: A Systematic Review on Progress and Perspectives. Membranes 2020, 10, 146. [CrossRef] [PubMed]

35. Bazinet, L.; Doyen, A.; Roblet, C. Electrodialytic Phenomena, Associated Electromembrane Technologies and Applications in the Food, Beverage and Nutraceutical Industries; Woodhead Publishing Limited: Sawston, UK, 2013; pp. 202-218.

36. Wang, Y.; Jiang, C.; Bazinet, L.; Xu, T. Electrodialysis-Based Separation Technologies in the Food Industry. In Separation of Functional Molecules in Food by Membrane Technology; Academic Press: Cambridge, MA, USA, 2019; pp. 349-381.

37. Koeman-Stein, N.; Creusen, R.; Zijlstra, M.; Groot, C.; Broek, W.V.D. Membrane distillation of industrial cooling tower blowdown water. Water Resour. Ind. 2016, 14, 11-17. [CrossRef]

38. Ma, J.; Irfan, H.M.; Wang, Y.; Feng, X.; Xu, D. Recovering Wastewater in a Cooling Water System with Thermal Membrane Distillation. Ind. Eng. Chem. Res. 2018, 57, 10491-10499. [CrossRef]

39. Kebria, M.R.S.; Rahimpour, A. Membrane Distillation: Basics, Advances, and Applications. Advances in Membrane Technologies; Abdelrasoul, A., Ed.; IntechOpen: London, UK, 2020. [CrossRef]

40. Abraham, T.; Luthra, A. Socio-economic \& technical assessment of photovoltaic powered membrane desalination processes for India. Desalination 2011, 268, 238-248. [CrossRef]

41. Karanasiou, A.; Kostoglou, M.; Karabelas, A. An Experimental and Theoretical Study on Separations by Vacuum Membrane Distillation Employing Hollow-Fiber Modules. Water 2018, 10, 947. [CrossRef]

42. Kiss, A.A.; Readi, O.M.K. An industrial perspective on membrane distillation processes. J. Chem. Technol. Biotechnol. 2018, 93, 2047-2055. [CrossRef]

43. Pangarkar, B.; Deshmukh, S.; Sapkal, V. Review of membrane distillation process for water purification. Desalin. Water Treat. 2014, 57, 2959-2981. [CrossRef]

44. Bappy, P.; Jabed, M.; Bahar, R.; Ariff, T.F. Low Energy and Low Cost Freshwater Production by Membrane Distillation. In Proceedings of the International Conference on Industrial Engineering and Operations Management, Kuala Lumpur, Malaysia, 8-10 March 2016; pp. 1799-1804.

45. Shirazi, M.M.A.; Kargari, A. A Review on Applications of Membrane Distillation (MD) Process for Wastewater Treatment. J. Membr. Sci. Res. 2015, 1, 101-112.

46. BioTech Water Researchers. Advantages and Disadvantages of Reverse Osmosis; BioTech Water Researchers: San Antonio, TX, USA, 2019.

47. Farahani, M.H.D.A.; Borghei, S.M.; Vatanpour, V. Recovery of Cooling Tower Blowdown Water for Reuse: The Investigation of Different Types of Pretreatment Prior Nanofiltration and Reverse Osmosis. J. Water Process Eng. 2016, 10, 188-199. [CrossRef]

48. Rabiee, H.; Khalilpour, K.R.; Betts, J.M.; Tapper, N. Energy-Water Nexus: Renewable-Integrated Hybridized Desalination Systems. In Polygeneration with Polystorage for Chemical and Energy Hubs; Academic Press: Cambridge, MA, USA, 2019 ; pp. 409-458.

49. Elaine, H.; Doerge, T.A.; Baker, P.B. Water Facts: Number 6 Reverse Osmosis Units. no. 6.1994. Available online: https: / / files.knowyourh2o.com/Waterlibrary/privatewell/ reverseosmosis.pdf (accessed on 28 November 2021). 
50. Macedo, A.T.Z.N.; Pulido, J.M.O.; Fragoso, R. The Use and Performance of Nanofiltration Membranes for Agro-Industrial Effluents Purification. In Nanofiltration; IntechOpen: London, UK, 2018; p. 65. [CrossRef]

51. Abdel-Fatah, M.A. Nanofiltration systems and applications in wastewater treatment: Review article. Ain Shams Eng. J. 2018, 9 , 3077-3092. [CrossRef]

52. Shon, H.K.; Phuntsho, S.; Chaudhary, D.S.; Vigneswaran, S.; Cho, J. Nanofiltration for water and wastewater treatment-A mini review. Drink. Water Eng. Sci. 2013, 6, 47-53. [CrossRef]

53. Shahmansouri, A.; Bellona, C. Nanofiltration technology in water treatment and reuse: Applications and costs. Water Sci. Technol. 2015, 71, 309-319. [CrossRef]

54. Leong, J.; Tan, J.; Heitz, A.; Ladewig, B.P. Use of vibratory shear enhanced processing to treat magnetic ion exchange concentrate: A techno-economic analysis. Desalination 2016, 383, 46-52. [CrossRef]

55. Zouboulis, A.I.; Peleka, E.N.; Ntolia, A. Treatment of Tannery Wastewater with Vibratory Shear-Enhanced Processing Membrane Filtration. Separations 2019, 6, 20. [CrossRef]

56. Balasubramanian, P. A Brief Review on Best Available Technologies for Reject Water (Brine) Management in Industries. Int. J. Environ. Sci. 2013, 3, 2010-2018.

57. Zouboulis, A.; Petala, M. Performance of VSEP vibratory membrane filtration system during the treatment of landfill leachates. Desalination 2008, 222, 165-175. [CrossRef]

58. Babu, D.S.; Singh, T.S.A.; Nidheesh, P.V.; Kumar, M.S. Industrial wastewater treatment by electrocoagulation process. Sep. Sci. Technol. 2020, 55, 3195-3227. [CrossRef]

59. Hernández, I.L.; Díaz, C.B.; Cerecero, M.V.; Sánchez, P.T.A.; Juárez, M.C.; Lugo, V.L. Soft drink wastewater treatment by electrocoagulation-electrooxidation processes. Environ. Technol. 2016, 38, 433-442. [CrossRef] [PubMed]

60. Mollah, M.Y.; Morkovsky, P.; Gomes, J.A.; Kesmez, M.; Parga, J.; Cocke, D.L. Fundamentals, present and future perspectives of electrocoagulation. J. Hazard. Mater. 2004, 114, 199-210. [CrossRef]

61. Akyol, A. Treatment of paint manufacturing wastewater by electrocoagulation. Desalination 2012, 285, 91-99. [CrossRef]

62. El-Ashtoukhy, E.S.Z.; El-Taweel, Y.A.; Abdelwahab, O.; Nassef, E.M. Treatment of Petrochemical Wastewater Containing Phenolic Compounds by Electrocoagulation Using a Fixed Bed Electrochemical Reactor. Int. J. Electrochem. Sci. 2013, 8, 1534-1550.

63. Zhao, S.; Huang, G.; Cheng, G.; Wang, Y.; Fu, H. Hardness, COD and turbidity removals from produced water by electrocoagulation pretreatment prior to Reverse Osmosis membranes. Desalination 2014, 344, 454-462. [CrossRef]

64. Mansour, S.; Hasieb, I. Removal of Nickel from Drinking Water by Electrocoagulation Technique Using Alternating Current. Curr. Res. Chem. 2012, 4, 41-50. [CrossRef]

65. Hashim, K.S.; Shaw, A.; Al Khaddar, R.; Pedrola, M.O.; Phipps, D. Iron removal, energy consumption and operating cost of electrocoagulation of drinking water using a new flow column reactor. J. Environ. Manag. 2017, 189, 98-108. [CrossRef] [PubMed]

66. Golder, A.; Samanta, A.; Ray, S. Removal of trivalent chromium by electrocoagulation. Sep. Purif. Technol. 2007, 53, 33-41. [CrossRef]

67. Silva, J.F.; Graça, N.S.; Ribeiro, A.; Rodrigues, A.E. Electrocoagulation process for the removal of co-existent fluoride, arsenic and iron from contaminated drinking water. Sep. Purif. Technol. 2018, 197, 237-243. [CrossRef]

68. Hashim, K.S.; Alkhaddar, R.; Jasim, N.; Shaw, A.; Phipps, D.; Kot, P.; Pedrola, M.O.; Alattabi, A.W.; Abdulredha, M.; Alawsh, R. Electrocoagulation as a green technology for phosphate removal from river water. Sep. Purif. Technol. 2019, 210, 135-144. [CrossRef]

69. An, C.; Huang, G.; Yao, Y.; Zhao, S. Emerging usage of electrocoagulation technology for oil removal from wastewater: A review. Sci. Total Environ. 2017, 579, 537-556. [CrossRef]

70. Islam, S.M.D.-U. Electrocoagulation (EC) technology for wastewater treatment and pollutants removal. Sustain. Water Resour. Manag. 2019, 5, 359-380. [CrossRef]

71. Moussa, D.T.; El-Naas, M.H.; Nasser, M.; Al-Marri, M.J. A comprehensive review of electrocoagulation for water treatment: Potentials and challenges. J. Environ. Manag. 2017, 186, 24-41. [CrossRef]

72. Nariyan, E.; Sillanpää, M.; Wolkersdorfer, C. Electrocoagulation treatment of mine water from the deepest working European metal mine-Performance, isotherm and kinetic studies. Sep. Purif. Technol. 2017, 177, 363-373. [CrossRef]

73. Anwer, E.A.; Majeed, B.A.A. Different Electrodes Connections in Electrocoagulation of Synthetic Blow down Water of Cooling Tower. Iraqi J. Chem. Pet. Eng. 2020, 21, 1-7. [CrossRef]

74. Kumar, S.; Ghosh, N.C.; Kazmi, A.A. Ballasted sand flocculation for water, wastewater and CSO treatment. Environ. Technol. Rev. 2016, 5, 57-67. [CrossRef]

75. Kumar, S.; Kazmi, A.A.; Ghosh, N.C.; Singh, R. Optimization of Ballasted Sand Flocculation Process for Urban Runoff Treatment J. Indian Water Resour. Soc. 2018, 37. Available online: http://117.252.14.250:8080/jspui/handle/123456789/4895 (accessed on 28 November 2021).

76. Kazmi, A.A.; Kumar, S.; Ghosh, N.C. Ballasted Sand Flocculation Technology for Storm Water Run Off Treatmnet. In Proceedings of the 21st International Water Technology Conference, Port Said, Egypt, 28-30 June 2018; pp. 28-30.

77. Veolia Water Technology. Actiflo®Sand-Ballasted Water Clarification and Softening Processes. Available online: https://www. oilandgasonline.com/doc/actiflo-ballasted-water-clarification-system-0001 (accessed on 28 November 2021).

78. Sauvignet, P. Sand-Ballasted Flocculation Technology and Mobile Facilities. Quarry Manag. 2003, 30, 17-18. 
79. Treguer, R.; Blair, B.; Klaper, R.; Royer, S.; Magruder, C. Evaluation of Actiflo ${ }^{\circledR}$ Carb Process for the Combined Removal of Trace Organic Compounds and Phosphorous during Wastewater Tertiary Treatment. Proc. Water Environ. Fed. 2012, 2012, 7176-7196. [CrossRef]

80. Akhter, M.; Habib, G.; Qamar, S.U. Application of Electrodialysis in Waste Water Treatment and Impact of Fouling on Process Performance. J. Membr. Sci. Technol. 2018, 8, 1000182. [CrossRef]

81. Mahmoudi, H. Encyclopedia of Membranes; Springer: Berlin/Heidelberg, Germany, 2015; pp. 1-2.

82. Qasim, M.; Badrelzaman, M.; Darwish, N.N.; Darwish, N.A.; Hilal, N. Reverse osmosis desalination: A state-of-the-art review. Desalination 2019, 459, 59-104. [CrossRef]

83. Trishitman, D.; Cassano, A.; Basile, A.; Rastogi, N.K. Reverse osmosis for industrial wastewater treatment. In Current Trends and Future Developments on (Bio-) Membranes; Elsevier: Amsterdam, The Netherlands, 2020; pp. 207-228.

84. Singh, R. Desalination and On-site Energy for Groundwater Treatment in Developing Countries Using Fuel Cells. In Emerging Membrane Technology for Sustainable Water Treatment; Elsevier: Amsterdam, The Netherlands, 2016; pp. 135-162.

85. Culkin, B. Eccentric Drive Mechanism. U.S. Patent US5014564A, 14 May 1991. Available online: https:// patents.google.com/ patent/US5014564A/en (accessed on 28 November 2021).

86. EMIS. Energie-En Milieu-Informatiesysteem Voor Het Vlaamse Gewest. 2020. Available online: https://emis.vito.be/nl (accessed on 28 November 2021).

87. Al-Karaghouli, A.; Kazmerski, L.L. Energy consumption and water production cost of conventional and renewable-energypowered desalination processes. Renew. Sustain. Energy Rev. 2013, 24, 343-356. [CrossRef]

88. Chaoui, I.; Abderafi, S.; Vaudreuil, S.; Bounahmidi, T. Water desalination by forward osmosis: Draw solutes and recovery methods-Review. Environ. Technol. Rev. 2019, 8, 25-46. [CrossRef]

89. Kim, I.S.; Hwang, M.; Choi, C. Membrane-Based Desalination Technology for Energy Efficiency and Cost Reduction. In Desalination Sustainability (A Technical, Socioeconomic, and Environmental Approach); Elsevier: Amsterdam, The Netherlands, 2017; pp. 31-74.

90. Mulyanti, R.; Susanto, H. Wastewater Treatment by Nanofiltration Membranes. IOP Conf. Ser. Earth Environ. Sci. 2018, 142, 012017. [CrossRef]

91. Strathmann, H. Encyclopedia of Membranes; Springer: Berlin/Heidelberg, Germany, 2015. [CrossRef]

92. Binot, P.; Dahl, C.P.; Zuback, J.E. Methods of Treating Water Via Ballasted Flocculation and. Decantation. Patent CA2471034C, 24 April 2012.

93. Sharma, G.; Choi, J.; Shon, H.K.; Phuntsho, S. Solar-powered electrocoagulation system for water and wastewater treatment. Desalin. Water Treat. 2011, 32, 381-388. [CrossRef]

94. Hafez, O.M.; Shoeib, M.A.; El-khateeb, M.A.; Abdel-shafy, H.I.; Youssef, A.O. Pt Graphical Abstract Sc B; Surface Coating Department, Central Metallurgical Research and Development Institute: Cairo, Egypt, 2018.

95. Bushart, S.; Tran, P.; Asay, R. Low-Level Liquid Waste Processing Pilot Studies Using a Vibratory Shear Enhanced Process (Vsep) for Fultration; WM Symposia, Inc.: Tucson, AZ, USA, 2002; pp. 1-8.

96. Wateronline. End of Pipe Effluent Treatment for Pulp and Paper Mills 2021. Available online: https://www.wateronline.com/ doc/end-of-pipe-effluent-treatment-for-pulp-and-p-0001 (accessed on 28 November 2021).

97. Jin, X.; Li, E.; Lu, S.; Qiu, Z.; Sui, Q. Coking Wastewater Treatment for Industrial Reuse Purpose: Combining Biological Processes with Ultrafiltration, Nanofiltration and Reverse Osmosis. J. Environ. Sci. 2013, 25, 1565-1574. [CrossRef]

98. VSEP. Applications-New Logic Research. Available online: https://www.vsep.com/technology/applications/ (accessed on 19 June 2021).

99. New Logic Research. Membrane Filtration of Cooling Tower Blowdown Application. Available online: https://www.vsep.com/ pdf/Membrane-Treatment-of-Cooling-Tower-Blowdown.pdf (accessed on 28 November 2021).

100. Fayad, N. The Application of Electrocoagulation Process for Wastewater Treatment and for the Separation and Purification of Biological Media. Master's Thesis, Université Clermont Auvergne, Clermont-Ferrand, France, 2018; pp. 5-226.

101. Westerling, K. ED vs. RO the Benefits of Electrodialysis for Desalination. 2015. Available online: https:/ / www.wateronline.com/ doc/ed-vs-ro-the-benefits-of-electrodialysis-for-desalination-0001 (accessed on 28 November 2021).

102. Mendez, E. Sustainable Desalination: Membrane Distillation Delivers Greener Clean Water-Filtration + Separation. 2012 Available online: https:/ / www.filtsep.com/desalination/features/sustainable-desalination-membrane-distillation/ (accessed on 28 November 2021).

103. Cui, H.; Huang, X.; Yu, Z.; Chen, P.; Cao, X. Application progress of enhanced coagulation in water treatment. RSC Adv. 2020, 10, 20231-20244. [CrossRef]

104. USEPA. Wastewater Technology Fact Sheet Dechlorination; Environmental Protection Agency: Washington, DC, USA, $2000 ;$ pp. 1-7.

105. Samcotech. Reverse Osmosis Vs Nanofiltration Membrane Process: What Is the Difference? Samcotech: New York, NY, USA, 2017.

106. Singh, K.; Lataye, D.H.; Wasewar, K.L.; Yoo, C.K. Removal of fluoride from aqueous solution: Status and techniques. Desalin. Water Treat. 2013, 51, 3233-3247. [CrossRef]

107. Mondal, S.; Wickramasinghe, S.R. Produced water treatment by nanofiltration and reverse osmosis membranes. J. Membr. Sci. 2008, 322, 162-170. [CrossRef]

108. Madaeni, S.; Samieirad, S. Chemical cleaning of reverse osmosis membrane fouled by wastewater. Desalination 2010, $257,80-86$. [CrossRef] 
109. EMIS. Nanofiltration. 2010. Available online: https://emis.vito.be/en/bat/tools-overview/sheets/nanofiltration (accessed on 28 November 2021).

110. Al-Amshawee, S.; Yunus, M.Y.B.M.; Azoddein, A.A.M.; Hassell, D.G.; Dakhil, I.H.; Hasan, H.A. Electrodialysis desalination for water and wastewater: A review. Chem. Eng. J. 2019, 380, 122231. [CrossRef]

111. Subramani, A.; De Carolis, J.; Pearce, W.; Jacangelo, J.G. Vibratory shear enhanced process (VSEP) for treating brackish water reverse osmosis concentrate with high silica content. Desalination 2012, 291, 15-22. [CrossRef]

112. Massot, A.; Mietton-Peuchot, M.; Peuchot, C.; Milisic, V. Nanofiltration and Reverse Osmosis in Winemaking. Desalination 2008, 231, 283-289. [CrossRef]

113. Zeynali, R.; Akbari, M.; Ghasemzadeh, K.; Jalilnejad, E.; Basile, A. Chapter 4-Achievements in High Pressure Membrane Processes Nf and Ro for Wastewater and Water Treatment; Elsevier: Amsterdam, The Netherlands, 2020.

114. Water, Produced, and Bilge Water. Using Vsep to Treat Produced Water. 1993. Available online: https://www.vsep.com/pdf/ ProducedWater.pdf (accessed on 28 November 2021).

115. Biniaz, P.; Ardekani, N.T.; Makarem, M.A.; Rahimpour, M.R. Water and Wastewater Treatment Systems by Novel Integrated Membrane Distillation (MD). ChemEngineering 2019, 3, 8. [CrossRef]

116. Luo, W.; Phan, H.V.; Li, G.; Hai, F.; Price, W.E.; Elimelech, M.; Nghiem, L.D. An Osmotic Membrane Bioreactor-Membrane Distillation System for Simultaneous Wastewater Reuse and Seawater Desalination: Performance and Implications. Environ. Sci. Technol. 2017, 51, 14311-14320. [CrossRef]

117. Wang, P.; Chung, T.S. Recent Advances in Membrane Distillation Processes: Membrane Development, Configuration Design and Application Exploring. J. Membr. Sci. 2015, 474, 39-56. [CrossRef]

118. Ghyselbrecht, K.; Van Houtte, E.; Pinoy, L.; Verbauwhede, J.; Van der Bruggen, B.; Meesschaert, B. Treatment of RO concentrate by means of a combination of a willow field and electrodialysis. Resour. Conserv. Recycl. 2012, 65, 116-123. [CrossRef]

119. Bartels, C.; Wilf, M.; Andes, K.; Iong, J. Design considerations for wastewater treatment by reverse osmosis. Water Sci. Technol. 2005, 51, 473-482. [CrossRef]

120. Luminor. Reverse Osmosis Water Filtration Overview. 2021. Available online: https://www.luminoruv.com/education/reverseosmosis (accessed on 28 November 2021).

121. Van Der Bruggen, B.; Vandecasteele, C. Removal of Pollutants from Surface Water and Groundwater by Nanofiltration: Overview of Possible Applications in the Drinking Water Industry. Environ. Pollut. 2003, 122, 435-445. [CrossRef]

122. Tibebe, D.; Kassa, Y.; Bhaskarwar, A.N. Treatment and characterization of phosphorus from synthetic wastewater using aluminum plate electrodes in the electrocoagulation process. BMC Chem. 2019, 13, 107. [CrossRef]

123. Uludag-Demirer, S.; Olson, N.; Ives, R.; Nshimyimana, J.P.; Rusinek, C.A.; Rose, J.B.; Liao, W. Techno-Economic Analysis of Electrocoagulation on Water Reclamation and Bacterial/Viral Indicator Reductions of a High-Strength Organic WastewaterAnaerobic Digestion Effluent. Sustainability 2020, 12, 2697. [CrossRef]

124. Pirsaheb, M.; Khosravi, T.; Sharafi, K.; Mouradi, M. Comparing operational cost and performance evaluation of electrodialysis and reverse osmosis systems in nitrate removal from drinking water in Golshahr, Mashhad. Desalin. Water Treat. 2015, 57, 5391-5397. [CrossRef]

125. Kullab, A.; Martin, A. Membrane distillation and applications for water purification in thermal cogeneration plants. Sep. Purif. Technol. 2011, 76, 231-237. [CrossRef]

126. Young, J.C.; Edwards, F.G. Factors affecting ballasted flocculation reactions. Water Environ. Res. 2003, 75, 263-272. [CrossRef] [PubMed]

127. Birnhack, L.; Nir, O.; Lahav, O. Establishment of the Underlying Rationale and Description of a Cheap Nanofiltration-Based Method for Supplementing Desalinated Water with Magnesium Ions. Water 2014, 6, 1172-1186. [CrossRef]

128. Elazhar, F.; Touir, J.; Elazhar, M.; Belhamidi, S.; El Harrak, N.; Zdeg, A.; Hafsi, M.; Amor, Z.; Taky, M.; Elmidaoui, A. Technoeconomic comparison of reverse osmosis and nanofiltration in desalination of a Moroccan brackish groundwater. Desalin. Water Treat. 2014, 55, 2471-2477. [CrossRef]

129. US Department of the Interior Bureau of Reclamation. Brine-Concentrate Treatment and Disposal Options Report-Part 1; US Department of the Interior Bureau of Reclamation: Washington, DC, USA, 2009; pp. 1-46.

130. Qureshi, A.S. Challenges and Prospects of Using Treated Wastewater to Manage Water Scarcity Crises in the Gulf Cooperation Council (GCC) Countries. Water 2020, 12, 1971. [CrossRef]

131. Chin, D.A. Water-Quality Engineering in Natural Systems: Fate and Transport Processes in the Water Environment; John Wiley \& Sons: Hoboken, NJ, USA, 2013; Volume 50.

132. EPA. Guidelines for Water Reuse; EPA: Washington, DC, USA, 2012.

133. IAEA. Executive by-Law for the Environment Protection Law. Supreme Council for the Environment E Natural Reserves Decree Law No. 30; Supreme Council for the Environment \& Natural Reserves: Doha City, Qatar, 2002.

134. Al-Muzaini, M.; Mendonca, V.; Al-Sariri, T.; Al-Jabri, M. Waste Water Discharge into the Marine Environment in the Sultanate of Oman: Sources and Standards-An Overview of the Current Situation. In Proceedings of the 3rd Marine Waste Water Discharges (MWWD), Catania, Italy, 27 September-2 October 2004.

135. Abu Dhabi Specification. Environmental Specifications for Land-Based Liquid Discharges to the Marine Environment; Abu Dhabi Quality \& Conformity Council: Abu Dhabi, United Arab Emirates, 2017. 